Pamiętnik Literacki 2020, 3, s. 119-128

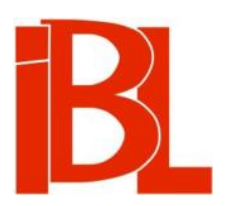

\title{
Sprostowania oraz uzupelnienia do genealogii i biografii Ludwika Sztyrmera
}

Dorota Samborska-Kukuć, Dariusz Kukuć 
Pamiętnik Literacki CXI, 2020, z. 3, PL ISSN 0031-0514

DOI: $10.18318 / \mathrm{pl} .2020 .3 .8$

DOROTA SAMBORSKA-KUKUĆ Uniwersytet Łódzki

DARIUSZ KUKUĆ

\section{SPROSTOWANIA ORAZ UZUPEENIENIA DO GENEALOGII I BIOGRAFII LUDWIKA SZTYRMERA}

W ostatnich latach daje się zauważyć wyraźny powrót do uwarunkowań biograficznych wspomagających interpretację utworu literackiego; to odejście od strukturalistycznego badania tekstu wydaje się drogą wiodącą od unilateralności do pewnej holistyczności eksplikacyjnej, obejmującej rozmaite konteksty wpływające na powstanie dzieła. Jedną z konsekwencji jest namysł nad poprawnością rekonstrukcji biograficznych, nad możliwością, a nawet koniecznością ich weryfikacji. W znacznym stopniu dotyczy to tych autorów, których dzieła podejrzewa się o aspekt autobiograficzny. W grupie takich twórców jest Ludwik Sztyrmer ${ }^{1}$.

Sądzić by wypadało, że ustalenia życiorysowe dotyczące tak znanych, jak Sztyrmer, pisarzy powinny być jeśli nie możliwie najszersze, to przynajmniej rzetelne, oparte na fundamencie źródeł archiwalnych. Powinny, ale nie zawsze są. Miejscem docelowym, przeznaczonym dla solidnie przygotowanych biogramów wydaje się przede wszystkim Polski słownik biograficzny, renomowana publikacja wielotomowa polskiej humanistyki, zainicjowana jeszcze w okresie międzywojennym. Obok wielu haseł zredagowanych wzorowo są tam wszakże omówienia ułomne, a nawet apokryficzne, bo ich autorzy czerpali z prac gotowych, nierzadko przestarzałych, bez weryfikacji powielając zawarte w nich treści i nie zadając sobie trudu przeprowadzenia rzetelnych poszukiwań. O ile w stosunku do haseł daw-

1 Autobiografizmu powieści Sztyrmera nie da się zdezawuować. Gdy konfrontuje się szczegóły temporalno-przestrzenne z zapisków pamiętnikarskich autora Powieści nieboszczyka Pantofla z jego utworami literackimi, łatwo dostrzec zbieżności; na ów aspekt zwracano uwage dawniej (m.in. M. In gl ot, O powieściach Sztyrmera w latach 1838-1844. „Pamiętnik Literacki” 1964, z. 3), dziś ten temat przywracają dwie badaczki: I. Węgrzyn (W labiryntach własnej biografii. Ludwik Sztyrmer - Wincenty Pantofel - Eleonora Sztyrmer. W zb.: Oblicza Narcyza. Obecność autora w dziele. Red. M. Cieśla-Korytowska, I. Pu chalska, M. Siwiec. Kraków 2008; „Pantofel. Historia mojego kuzyna" Ludwika Sztyrmera. Wariacje na temat małej biografii i wielkiej biblioteki. „Wiek XIX. Rocznik Towarzystwa im. Adama Mickiewicza” 2009) oraz E. O w c zarz (Powieści nieboszczyka Pantofla. Sztyrmerowskie dażenie do petni. W: Nieosiagalna całość. Szkice o powieści polskiej XIX wieku. Józef Ignacy Kraszewski - Ludwik Sztyrmer - Henryk Sienkiewicz. Toruń 2009, s. 156-163, 197).

Jako przeciwwagę autobiografizmu można w tym miejscu przytoczyć opinię samego L. Sztyrm e r a (List z Polesia. II. „Tygodnik Petersburski” 1842, nr 92, s. 612), który zalecał „sądzić dzieło z wewnętrznej jego wartości [...], [z] tego, co się w nim zawiera”, traktując je niczym jakość immanentną i abstrahując od zależności pozatekstowych, by nie „widzieć nic więcej jak to, co napisano”. 
niejszych, przedwojennych czy realizowanych w okresie PRL-u, gdy niełatwo było o kwerendy zagraniczne, niekiedy zaś i krajowe, a rozpoznanie zbiorów archiwalnych bywało (funkcja zmienna w czasie) wysoce niezadowalające, praktykę taką można by częściowo usprawiedliwić, o tyle coraz trudniej znaleźć przekonujące uzasadnienie niesolidności prac współczesnych. Sporządzony przed paru laty przez Artura Kijasa biogram Ludwika Sztyrmera ${ }^{2}$ zawiera liczne niezweryfikowane repetycje, wynikające $\mathrm{z}$ braku rewizji danych; autor powtórzył utrwalone w kompendiach informacje, sam zaś nie sięgnął do nie eksplorowanych dotąd dokumentów podstawowych, na co wskazuje niedostatek źródeł rękopiśmiennych w podanej pod hasłem bibliografii. Takie potraktowanie poważnego zadania dziwi tym bardziej, że autorem jest - wydawałoby się - renomowany historyk, który z natury rzeczy powinien być zainteresowany rekonesansem $\mathrm{w}$ zbiorach archiwów. $\mathrm{W}$ tej sytuacji należy dokonać reasumpcji biogramu, mogącego posłużyć literaturoznawcom do eksplikacji wspartych na elementach życiorysowych, w wyniku czego w miejsce błędnych domysłów, nie potwierdzonych żadnym poważniejszym źródłem, wprowadzone zostana ustalenia zgodne $\mathrm{z}$ odpowiednia, odnotowaną $\mathrm{w}$ przypisach dokumentacją.

W ramach tego skondensowanego tekstu nie ma potrzeby rozwodzić się nad opisami badacza dotyczącymi zawartości powieści i opowiadań Sztyrmera. Stwierdzić tylko należy, że komentarze do niektórych jego utworów są chybione, co może wynikać $z$ faktu, iż Kijas nie jest historykiem literatury, nie zna gruntownie bibliografii podmiotu i przedmiotu; dowodzi tego m.in. dość niefortunna merytorycznie, pomijana w literaturoznawczych opracowaniach cytacja z Kazimierza Czachowskiego odnosząca się do wspomnień autora Duszy w suchotach ${ }^{3}$, „Pamiętnik doprowadził [Sztyrmer] do 29 XI 1833; po latach został on uznany za "najciekawszy i najoryginalniejszy utwór polskiej prozy psychologicznej z pierwszej połowy XIX stulecia“"4. Tego cytatu nie użył - w swojej chybionej „monografii” - nawet Zdzisław Mrozek, mający skłonność do powielania cudzych wypowiedzi ${ }^{5}$. Warto też wskazać na nonsens zawarty w sformułowaniu opisującym krytyczny epizod Sztyrmera, który na łamach „Tygodnika Petersburskiego” z lat 1842-1843 rzekomo „rozprawiał się [...] z romantyczną konwencją polskiej literatury, atakując świat czarów, guseł i sennych widziadel"6. Gdyby autor hasła zapoznał się z opracowaniami na ten temat lub choćby sięgnął do wzmiankowanych artykułów $z$ petersburskiego dziennika, z pewnościa nie wyraziłby takiej opinii odnośnie do rozpraw krytycznych opublikowanych pod wspólnym tytułem Listy z Polesia ${ }^{7}$. Nietrafność przywołań

A. Ki j a s, Sztyrmer Ludwik. Hasło w: Polski słownik biograficzny. T. 49/1. Warszawa-Kraków 2013.

K. C z a c h ow s ki, Między romantyzmem a realizmem. Warszawa 1967, s. 289.

Kija s, op. cit., s. 144.

Z. M r o ze k, Literacki świat Ludwika Sztyrmera. Bydgoszcz 1990.

Kija s, op. cit., s. 144.

Zob. M. In gl ot, Sztyrmer Ludwik. Hasło w: Literatura polska. Przewodnik encyklopedyczny. T. 2. Warszawa 1985, s. 435. Zob. - też przede wszystkim - D. Ku k u ć, Ludwik Sztyrmer - krytyk na tamach „Tygodnika Petersburskiego”. W zb.: Polska krytyka literacka w XIX wieku. Red. M. S tr zyżewski. Torun 2005.

Nieadekwatna jest także konkluzja Kijasa (op. cit., s. 145) dotycząca „ostrej reakcji pentarchii” na 
i nierzetelność Kijasa podważa - niestety - zaufanie czytelnika do innych podanych przez niego ustaleń. W większości są one przepisane i skompilowane z gotowych źródeł, a oceny dzieł - dość przypadkowe.

Lapsus demaskujący brak weryfikacji źródeł dotyczy już daty urodzenia Sztyrmera. Wszystkie źródła drukowane podają: 30 IV $1809^{8}$. Tymczasem w oryginalnym akcie urodzenia data jest inna, o dzień późniejsza - 1 maja. Cały akt brzmi następująco:

Roku tysiącznego ośmsetnego dziewiątego, dnia czwartego miesiąca maja o godzinie 10-tej z rana przed nami, Urzędnikiem Stanu Cywilnego gminy Płońska powiatu wyszogrodzkiego w Departamencie Płockim, stawił się J[aś]nie Pan Ludwik Sztyrmer, urzędnik zdrowia klasy drugiej w Pułku Pierwszym Jazdy Wojska Księstwa Warszawskiego, liczący lat trzydzieści i sześć, w Płońsku zamieszkały, i okazał nam dziecię płci męskiej, które urodziło się w domu pod numerem czterdziestym pierwszym, na dniu pierwszym miesiąca maja roku tysiącznego ośmsetnego dziewiątego o godzinie ósmej z rana, oświadczając, iż jest spłodzone z niego i Julianny z Linkowskich, pierwszego ślubu Kraszewskiej, jego małżonki, i że życzeniem jego jest nadać mu imiona Karol Ludwig Konstanty. Po uczynieniu powyższego oświadczenia i okazania nam dziecięcia w przytomności Imci Pana Gotfrieda Bitnera, kapitana Gwardii Nacjonalnej, liczącego lat czterdzieści, w Płońsku zamieszkałego, tudzież Imci Pana Andrzeja Majorkiewicza, burmistrza policji, liczącego lat dwadzieścia i dziewięć, w Płońsku zamieszkałego. Akt niniejszy urodzenia został stawiającym przeczytany i podpisany tak przez oświadczającego, jako i świadków.

Jan Giełczewski, Urzędnik Stanu Cywilnego,

Ludwig Sztyrmer,

Godfryd Büttner, świadek,

A. Majorkiewicz, świadek ${ }^{9}$

Akt urodzenia przyszłego autora Powieści nieboszczyka Pantofla potwierdza zatem znane już miejsce przyjścia na świat - Płońsk, dookreślając jednak realia: numer hipoteczny 41 (dawna ulica Ciechanowska, obecnie Grunwaldzka), zmienia natomiast informacje utrwalone repetycjami: datę dzienna, imiona nowo narodzonego oraz imię ojca, a także, co poświadczają zapisy we wszystkich dalej tu przywoływanych aktach metrykalnych, pochodzenie obojga rodziców. Nie było ono bowiem mieszczańskie, jak to utrzymują dotychczasowi biografowie, ale szlacheckie - i to $z$ obu stron. Jak widać, Sztyrmer nie będzie posługiwał się pierwszym imieniem: Karol, ale drugim: Ludwik, tożsamym z imieniem ojca, któremu we

owe Listy z Polesia, do której badacz zaliczył i tekst M. Grab ow s ki e go O kilku literatach polskich $w$ Petersburgu (,Tygodnik Petersburski” 1842, nr 77), opublikowany jeszcze przed pierwszym artykułem krytycznym Sztyrmera (nr 88)!

8 Także data widniejąca na inskrypcji nagrobnej Sztyrmera na wileńskim cmentarzu na Rossie została starannie przeliczona na tzw. stary styl (18 IV) i zarówno potwierdza datowanie utrwalone w kompendiach (30 IV - według nowego stylu), jak i daje wyraz przeświadczeniu rodziny pisarza. USC gminy miasta Płońsk. Archiwum Państwowe w Warszawie, Oddział w Mławie, akt urodzenia nr 1/1809, s. 1 (zmodernizowana została ortografia oraz interpunkcja). Wszystkie przywoływane tu akty urodzin i zgonów są rękopiśmienne.

Dwaj świadkowie zgłoszenia urodzenia: Andrzej Majorkiewicz (1781-1853), syn Wojciecha (burmistrza Płońska) oraz Katarzyny z Guzanowskich, to naczelnik miejscowej policji; kapitan Gotfryd B ü t t n e r, o którym bliżej niewiele wiadomo, był sąsiadem Sztyrmerów, co wynika z innych dotyczących go akt. 
wszystkich opracowaniach czerpiących z niedoskonałego pod każdym względem studium Piotra Chmielowskiego ${ }^{10}$ przypisuje się imię Jakub.

Ojciec autora opowieści o Pantoflu, Ludwik Sztyrmer (lub obocznie Stürmer), urodzony w r. 1771, syn Jakuba i Petroneli ${ }^{11}$, pochodził prawdopodobnie $z$ terenu Prus; jak odnotowuje Franciszek Giedroyć, „służył w wojsku pruskim”12. Urzędnikiem zdrowia klasy II został mianowany 13 II 1808. Jako lekarz wojskowy służył w r. 1815 w 10 kompanii weteranów, a w 1830 - w kompanii 2 batalionu 2. W swoim wykazie podaje Giedroyć innego jeszcze Sztyrmera (Stürmera) - Jana, syna Jędrzeja i Ewy, urodzonego w Toruniu w r. 1773, lekarza wojskowego w 1 pułku jazdy. Zważywszy na tożsamość profesji, możliwe, że chodzi o krewnego, a nawet brata stryjecznego Ludwika seniora.

Dokumentacja metrykalna nie potwierdziła, by matka pisarza była drugą żoną jego ojca; pierwsza - według Chmielowskiego - miała się $z$ nim podobno rozwieść wskutek nadużywania przez niego alkoholu. Jak to dosadnie formułuje Chmielowski, Sztyrmer lekarz „odznaczał się surowością, mało rozwiniętym uczuciem, brakiem wychowania i nabytym w wojsku nałogiem pijaństwa"13. $Z$ jego aktu ślubu z pochodzącą $z$ Elblagga w Prusach Marianna Julianną Linkowską ${ }^{14}$, zawartego

10 P. Chmielows ki, Ludwik Sztyrmer. W: Nasi powieściopisarze. Warszawa 1895. Chmielowski opublikował fragmenty wspomnień autora Powieści nieboszczyka Pantofla zawierające poniektóre informacje $z$ wczesnych lat jego życia, zwłaszcza dotyczące kwestii rodzinnych, okresu szkolnego: nauczycieli i kolegów, zamiłowania do matematyki i literatury oraz komentarze o charakterze autoanalitycznym, nakreślające „portret artysty z czasów młodości”. Praca Chmielowskiego zażenowała wdowę po pisarzu, która osądziła ów tekst jako „ubliżający pamięci” jej męża, nie tylko wskutek pobieżnego, a nawet nietrafnego odczytania jego dzieł, ale także z powodu licznych faktograficznych przeinaczeń, których dziś już nie da się zweryfikować. Zob. A. W a li c k i, Wspomnienie o Sztyrmerach. „Kraj” 1892, nr 14, s. 6.

11 Informacje o wieku ojca i imionach jego rodziców, a dziadków pisarza „po mieczu” pochodzą z aktu zgonu: USC parafii Siedlce. Archiwum Państwowe w Siedlcach, akt zgonu nr 43/1830, k. 77. Błędne imię ojca: Jakub, mogło wynikać z niedokładnego odczytania rękopisu Sztyrmera przez Chmielowskiego, niewykluczone, że fragment wspomnieniowy mógł dotyczyć właśnie dziadka Jakuba.

12 F. Gi i d roy ć, Służba zdrowia w dawnym Wojsku Polskim. Warszawa 1927, s. 515.

13 Chmielow s ki, op. cit., s. 158. Nie znający Sztyrmera osobiście autor studium otrzymał od jego żony rękopisy, w tym wspomnienia i korespondencję. Bliżej nie określony notatnik Sztyrmera nie został Chmielowskiemu udostępniony, a korespondencję wykorzystał badacz tylko w niewielkim stopniu. Uznał, że metoda pracy polegająca na przeplataniu cytowań z własnymi streszczeniami będzie właściwa. Jednak nie jest; dla biografa szukającego konkretów faktograficznych, nie zaś interpretacji osób trzecich, tekst Chmielowskiego ma wartość wyłącznie połowiczną, tzn. o tyle, o ile zgadza się z oryginałem pamiętnika. Wzmianka o alkoholizmie ojca i rozwodzie ma postać streszczenia, jest wyjęta $z$ kontekstu. $Z$ innych partii wspomnień wynika jednoznacznie, że uczucia Sztyrmera do ojca były ambiwalentne, raz żywił wobec niego złość, a nawet pogardę, kiedy indziej miał poczucie winy i przejawiał skruchę.

14 Charakterystykę matki pisarza znamy jedynie z pracy Chmielowskiego. Podobno źle mówiła po polsku, „ale tak mile, że "niepodobna było się oprzeć jej słowom". Przy całej "prostocie swojej" miała ona "niepojęty urok" w twarzy, coś niewypowiedzianie "miłego i słodkiego w swych rysach". Uważana raczej za niewolnicę niż żonę, chociaż czasami obsypywana czułościami, ustępowała wszystkim słabościom męża, znosiła w milczeniu jego często twarde i srogie postępowanie, wstawiała się za nim u przełożonych i kilka razy zachowała mu usuwającą się już posadę. "Czułość jej była nadzwyczajną; najmniejsza okoliczność wzbudzała w niej potoki łez«; mała słabość jednego z dzieci o mało nie wpędziła jej do grobu” (Chmielowski, ibidem). Temu ostatniemu zdaniu 
26 VI 1808 w Płońsku, wynika jednak, że wstępując w związek małżeński, ojciec pisarza był jeszcze kawalerem ${ }^{15}$, ona zaś 28-letnią, czyli urodzoną około 1780 r., wdową po oficerze Szwadronu Huzarów Króla, Fryderyku Wilhelmie Kraszewskim (obocznie w różnych aktach także: Kruszewski). Jej zaślubiny z pierwszym mężem odbyły się w Konarach (pod Warka) w styczniu $1800^{16}$. Z pierwszego małżeństwa Linkowskiej przyszło na świat sześcioro dzieci: Jan Wilhelm (1800-?) ${ }^{17}$, Henryk Leopold (1801-1802), Karol Edward (1802-1803), Wilhelmina Julianna (1803-1848), Augustyna (1804-1808) ${ }^{18}$ oraz Ludwik Juliusz (1807-1807) ${ }^{19}$, z których niemal wszystkie zmarły w niemowlęctwie lub we wczesnym dzieciństwie. Prawdopodobnie tylko Wilhelmina dożyła wieku dorosłego ${ }^{20}$, zmarła podczas epidemii cholery w czterdziestym czwartym roku życia w Łęczycy ${ }^{21}$. Pierwszy mąż Marianny Julianny z Linkowskich zmarł w początkach kwietnia 1808 w Płońsku w wieku 37 lat $^{22}$. Wdowa, odczekawszy... niecałe trzy miesiące, poślubiła Sztyrmera. Niewykluczone, że był on - jako lekarz - znajomym lub nawet przyjacielem rodziny.

Wkrótce po urodzeniu Ludwika juniora, zapewne w końcu r. 1809 lub z początkiem roku następnego, Sztyrmerowie przeniesieni zostali do Warszawy i zamieszkali w domu Piotra Dyttlingera przy ulicy Zielonej pod numerem 2082; tam przyszła na świat ich córka Joanna Zuzanna Emilia (1810-?2) ${ }^{23}$, prawdopodobnie

trudno się dziwić, Marianna Julianna Sztyrmerowa miała z obu małżeństw trzynaścioro dzieci, z których tylko pięcioro dożyło wieku dorosłego, ośmioro musiała pochować. Egzaltacja, którą zdaje się sugerować jej syn, mogła zatem wynikać nie tyle z usposobienia, ile z nieustannej obawy o życie dzieci.

15 USC parafii Płońsk. Archiwum Diecezjalne w Płocku, sygn. 824, akt ślubu nienumerowany/1808, k. $56 \mathrm{v}$.

Małe jest prawdopodobieństwo, by ojciec Ludwika zataił swój stan cywilny, raczej była to więc mistyfikacja syna, który z jakichś powodów przypisywał ojcu tak rozwód, jak i nałogi oraz despotyczne zachowania. O ile cechy charakteru są nieweryfikowalne, trudno zaprzeczyć dokumentacji aktowej.

16 USC parafii Konary. Archiwum Archidiecezjalne w Warszawie, akt ślubu nienumerowany (1)/1800, k. 60 .

17 Jw., akt urodzenia nienumerowany/1800, k. 46.

18 Data narodzin ustalona na podstawie aktu zgonu: USC gminy miasta Płońsk. Archiwum Państwowe w Warszawie, Oddział w Mławie, akt zgonu nr 35/1808, s. 26; miejsce urodzenia nieznane.

19 Akty urodzenia Henryka, Karola, Wilhelminy i Ludwika: USC parafii Płońsk. Archiwum Diecezjalne w Płocku, sygn. 825, s. 264, 277, 298 i 346. Akty zgonów Henryka, Karola i Ludwika: USC parafii Płońsk. Archiwum Diecezjalne w Płocku, sygn. 823, s. 86, 98 i 138. Informacje także w Ogólnym sumariuszu alfabetycznym metryk urodzenia i chrztu, zaślubienia i zejścia w dwóch księgach dawnych metryk kościelnych parafii płońskiej od roku 1734 do 1808 zapisanych uformowanym (Archiwum Diecezjalne w Płocku, rkps 826, k. 34v, 35, 35v, 36 oraz 105, 105v, 106v). Nie udało się ustalić losów najstarszego syna Kraszewskich, Jana Wilhelma, nie wiadomo, w jakim wieku zmarł, pewne jest tylko, że nie stało się to ani w Konarach, ani w Płońsku.

21 USC parafii (św. Andrzeja) Łęczyca. Archiwum Państwowe w Łodzi, akt zgonu nr 253/1848. We wspomnieniach Sztyrmera nie jest ona przywołana ani razu, wydaje się więc, że wychowywała się gdzie indziej, może u rodziny swojego ojca; dopiero później, już w Łęczycy, będzie mieszkać przy matce, Mariannie Juliannie Sztyrmerowej.

22 USC parafii Płońsk, sygn. 823, akt zgonu nienumerowany/1808, s. 143. Informacja także w Ogólnym sumariuszu alfabetycznym [...] (k. 106v).

23 USC Warszawa / cyrkuł II. Archiwum Państwowe w Warszawie, akt urodzenia nr 281/1810. Z aktu wynika, że w r. 1810 Ludwik Sztyrmer senior stacjonował na terenie tzw. Nowej Galicji (prawdo- 
zmarła w dzieciństwie; następnie, już przy ulicy Freta 257, urodziły się Augusta Teofila (1812-?) ${ }^{24}$ i Józefina Rozalia Ludwika (1814-1881) ${ }^{25}$. Niewykluczone, że także w Warszawie urodziła się Karolina Franciszka (1816-1819), która zmarła w trzecim roku życia w Siedlcach ${ }^{26}$.

Po roku 1817, a może i wcześniej (nie jest wykluczone, że między r. 1815 a 1818 przebywali jeszcze gdzieś indziej), Sztyrmerowie przenieśli się do Siedlec, dokąd wraz z batalionem weteranów został oddelegowany ojciec pisarza. Zamieszkali przy Końskim Rynku 149. W Siedlcach przyszły na świat kolejne dwie córki Sztyrmerów: Rozalia Teofila (1818-?) ${ }^{27}$ oraz najmłodsza - Małgorzata Leokadia (1821-1884) ${ }^{28}$.

Spośród wszystkich rodzonych sióstr Ludwika juniora stosunkowo najwięcej informacji udało się uzyskać o dwóch z nich.

Józefina Rozalia Ludwika ${ }^{29}$ już w r. 1833 wyszła za mąż w Łęczycy jako dziewiętnastolatka za prawie 50-letniego Józefa Rakowskiego (syna Michała i Jadwigi z Kaletów), wdowca, nauczyciela obwodowej szkoły łęczyckiej ${ }^{30}$, zmarłego w roku 1851. Rakowscy mieli cztery córki: Kamilę Henrykę, Michalinę Salomeę, Teodorę Aleksandrę i Bronisławę Angelę. Józefina Rakowska przeżyła męża o 30 lat; nie weszła ponownie w związek małżeński, zmarła w Łęczycy w czerwcu $1881^{31}$.

Małgorzata Leokadia Sztyrmerówna (we wspomnieniach brata oraz w późniejszych dokumentach urzędowych występująca jako Leokadia), będąc guwernantką w Rożniatowie, została w połowie 1844 r. żoną artysty malarza Ferdynanda Cieślewskiego (syna Filipa i Rozalii) ${ }^{32}$. Mieszkała w Uniejowie, była matka Józefy (1844-1858) ${ }^{33}$ i Konrada (?-1851) ${ }^{34}$ oraz Aleksandry (Walentowej Szadkowskiej) i Filipiny (Tomaszowej Cieślewskiej). Zmarła w Uniejowie w czerwcu 1884, owdowiwszy męża ${ }^{35}$.

Natomiast nie udało się niczego pewnego ustalić ani o losach Augusty Teofili, ani o 6 lat od niej młodszej - Rozalii Teofili. Wzmiankowaną w pamiętniku Teofilę, podobno najbardziej namiętną i uczuciową, a przy tym wielkiej urody, „zachwycającej i czarującej”, można zapewne utożsamić (z uwagi na zawarte sugestie pisarza) ze starszą siostrą, Augustą Teofilą. Na odpowiedzialność tylko jednego $z$ autorów tego artykułu warto przytoczyć przeczytaną niegdyś informację, iż któraś (nie wymieniona z imienia) z sióstr Ludwika Sztyrmera zmarła w Petersburgu mniej więcej

podobnie w Staszowie), obszarze włączonym do Księstwa Warszawskiego w wyniku pokoju w Schönbrunn.

Jw., akt urodzenia nr 54/1812.

Jw., akt urodzenia nr 114/1814.

USC parafii Siedlce, akt zgonu nr 72/1819.

Jw., akt urodzenia nr 83/1818.

Jw., akt urodzenia nr 203/1821.

W ocenie brata Józefina „przejęła czułość matki, ale razem i popędliwość ojca” (C h m i elow s ki, op. cit., s. 159).

USC parafii (św. Andrzeja) Łęczyca, akt ślubu nr 54/1833.

Jw., akt zgonu nr 127/1881.

USC parafii Wielenin. Archiwum Państwowe w Poznaniu, Oddział w Koninie, akt ślubu nr 10/1844. USC parafii Uniejów. Archiwum Państwowe w Łodzi, akt zgonu nr 221/1858. Data urodzenia ustalona na podstawie aktu zgonu.

Jw., akt zgonu nr 147/1851.

Jw., akt zgonu nr 60/1884. 
$\mathrm{w}$ drugiej połowie lat czterdziestych ${ }^{36}$. Niestety, sporządzone niegdyś notatki z niepublikowanej korespondencji zaginęły i pomimo wysiłków nie udało się dojść do ich źródła. Zapewne była to albo Augusta, albo Rozalia.

Około r. 1818 oddano Ludwika do szkoły miejscowej (dla kandydatów na nauczycieli szkół elementarnych), zarządzanej przez dyrektora Jana Holewińskiego ${ }^{37}$, prowadzącego tam zajęcia $z$ geografii i historii. $W$ czasie wakacji - jak sam pisarz opowiada - uczęszczał... na pensję żeńską Anny Filemonowiczowej. W maju 1819 zmarła w Siedlcach babka Ludwika, Petronela Fiszowa 1 voto Stürmerowa ${ }^{38}$ - wydarzenie to Sztyrmer odnotował w pamiętniku. W sierpniu 1821 wstapił do kaliskiego czteroklasowego Korpusu Kadetów ${ }^{39}$, którego realia odmalował w swoich wspomnieniach niezwykle szczegółowo. Podobnie, z dbałością o detale przestrzenno-personalne, deskrybował pobyt w Szkole Wojskowej Aplikacyjnej przy ulicy Miodowej w Warszawie, do której przybył w 1825 r.; po napisaniu rozprawy z zakresu wojskowości został awansowany na podporucznika artylerii pieszej kompanii I pozycyjnej pod dowództwem Jana Leppigé.

31 III 1830 zmarł w Siedlcach ojciec Sztyrmera ${ }^{40}$. Uderzające są słowa syna:

Zgon jego był ciężki, bolesny, i palec Boga widocznie dotknął go w ostatniej chwili za błędy całego żywota [...]. Ostatnie jego słowa wyrażały zgryzotę, że zostawia żonę i dzieci bez sposobu do życia, mogąc im zapewnić los nieświetny, ale przynajmniej mierny i dostateczny, gdyby nie okropny nałóg pijaństwa, który wszystko zmarnotrawił, co mu talenta jego przyniosły ${ }^{41}$.

Wkrótce potem ${ }^{42}$ wdowa $\mathrm{z}$ córkami przeniosła się do Łęczycy, gdzie mieszkał jej młodszy brat Jan ${ }^{43}$. Po jego śmierci (1836 r.), a także już po zgonie bratanka (1840 r.) oraz bratowej (1845 r.) Sztyrmerowa nadal mieszkała w Łęczycy. Zmarła

Śmierć miała nastapić w czasie karnawału, gdy zgrzana tańcem kobieta napiła się zimnej wody (wtedy często tak właśnie tłumaczono sobie śmierć z powodu - jak pewnie było w tym przypadku zapalenia płuc).

37 Placówka J. Holewińskiego działała od roku szkolnego 1819/20 - zob. A. W ęc cow s ki, Kalendarium wydarzeń kulturalno-oświatowych $w$ Siedlcach. „Szkice Podlaskie” 1998, s. 115. Wcześniej, tj. od r. 1818, była to szkoła podwydziałowa - zob. Rocznik Instytutów Religijnych i Edukacyjnych. Warszawa 1924, s. 200-201, gdzie również zamieszczono wykaz nauczycieli siedleckiej szkoły. USC parafii Siedlce, akt zgonu nr 91/1819.

Miejscu temu i okresowi adolescencji poświęca Sztyrmer - jak wnosić wypada ze streszczeń Chmielowskiego - dość dużo miejsca. Sam Chmielowski nakreśla szczegółowe tło, przywołując nie tylko nazwiska nauczycieli, ale i sposoby kształcenia, wygląd budynku, etc.

USC parafii Siedlce. Archiwum Państwowe w Siedlcach, akt zgonu nr 43/1830, k. 77.

Chmielowski, op. cit., s. 204.

42 Zaraz po śmierci męża Marianna Julianna Sztyrmerowa mieszkała jeszcze jakiś czas w Siedlcach, jak to wspomina Ludwik, „w dwu pokoikach”. Zgodnie z jego relacja, przeprowadziła się do Łęczycy w 1831 r.; jesienią 1833 ślub w kolegiacie łęczyckiej wzięła Józefina Rozalia Ludwika Sztyrmerówna - zob. USC parafii (św. Andrzeja) Łęczyca, akt ślubu nr 54/1833.

43 Chodzi o Jana Henryka Linkowskiego (1784-1836), wuja Sztyrmera pisarza, o którym co najmniej dwukrotnie wzmiankował on we wspomnieniach, odtwarzając wakacje r. 1823 spędzone w Łęczycy. Dom Linkowskiego i jego żony, Katarzyny z Mamińskich 1 voto Mateuszowej Naymanowicz (1771-1845), znajdował się faktycznie w rynku, przy ul. Targowej (dziś Jana Pawła II) - zob. „Dziennik Powszechny Krajowy” 1831, nr 70, s, 566. Syn Linkowskich, Józef (1810-1840), rówieśny Ludwika Sztyrmera - jako nazbyt dynamiczny - nie przypadł mu do gustu; Józef Linkowski był urzędnikiem Trybunału Radomskiego. 
po $1848 \mathrm{r}^{44}$; w akcie zgonu jej córki z pierwszego małżeństwa - Wilhelminy Julianny Kraszewskiej - widnieje informacja: „panna mieszkająca przy matce” 45 .

Nie mniejszych uzupełnień i korekt wymaga także fragment biogramu Ludwika Sztyrmera obejmujacy jego małżeństwo i progeniturę. $Z$ relacji Chmielowskiego wiadomo, że około r. 1838 ożenił się z Eleonorą Janowską, córką Jana, lekarza z Witebska (lub Połocka) ${ }^{46}$, i nie znanej z imienia matki ze Swarackich ${ }^{47}$. Janowska była wychowanka jednej $z$ dwu pensji: istniejącego od 1834 r. kijowskiego Instytutu Szlacheckich Panien lub Instytutu Panien, funkcjonującego od $1835 \mathrm{roku}^{48}$. Nie wiadomo, gdzie Sztyrmer poznał swą przyszłą żonę ani gdzie odbyły się ich zaślubiny. Chmielowski wiadomości te przemilczał, o ile w ogóle był w ich posiadaniu ${ }^{49}$. $Z$ inskrypcji nagrobnej na wileńskiej Rossie wynika, że Eleonora Janowska urodziła się 11 I $1815^{50}$. W związku z zawarciem małżeństwa lub krótko przed tym wydarzeniem napisał Sztyrmer L'hymen, 19-punktowy kodeks przeznaczony dla żony ${ }^{51}$.

Biografowie Sztyrmera są dalece nieprecyzyjni także w kwestii jego progenitury. Kijas - za poprzednikami - pisze o czworgu dzieciach, choć tylko dwoje wskazuje $z$ imienia: córkę Aleksandrę i syna Jana (zreszta jako Iwana, sugerując tym samym zachodzacy $\mathrm{w}$ rodzinie proces wynarodowienia). Tymczasem kwerenda w aktach metrykalnych petersburskich oraz wileńskich pozwoliła na bardziej dokładne ustalenie faktów dotyczących potomstwa Sztyrmerów, choć z uwagi na niekompletność danych trudno podać kolejność poszczególnych narodzin. Nie wiadomo też, czy wszystkie dzieci przyszły na świat w Petersburgu. Najstarszą córką pisarza była najpewniej Aleksandra (1839-1904) urodzona 1/13 VI $1839^{52}$.

Aktu zgonu Marianny Julianny Sztyrmerowej nie odnaleziono ani w Łęczycy (akta są tam kompletne), gdzie mieszkała córka, Józefina Rozalia Ludwika Rakowska, ani w Uniejowie, miejscu zamieszkania drugiej córki, Małgorzaty Leokadii Cieślewskiej.

USC parafii (św. Andrzeja) Łęczyca. Archiwum Państwowe w Łodzi, akt zgonu nr 253/1848.

Połock jako - raczej niepewne - miejsce urodzenia Eleonory Janowskiej podaje Encyklopedia powszechna Orgelbranda (t. 14. Warszawa 1903, s. 295).

Wkrótce wejdzie Sztyrmer w koligacje rodzinne z młodą pisarką Karoliną z Hołow ni ó w S waracka (1815-1846), która w 1841 r. poślubi wuja (brata matki) Eleonory Sztyrmerowej. Zob. D. Kukuć, Swaracka Karolina. Hasło w: Polski słownik biograficzny, t. 46/1 (Kraków 2009), s. 119.

Zob. Rys systemu, postępów i stanu oświecenia publicznego w Rosji. Warszawa 1838, s. 387-388. Jeśli potraktować twórczość literacką Sztyrmera jako tekst qusi-autobiograficzny, można przypuszczać, że poznał on Eleonorę w Witebsku. Taką formułę badawczą wobec styków: pisarstwo-biografia proponuje W ę g rzy n (W labiryntach własnej biografii); zob. też A. Ro ma now s ki, Prawdziwy koniec Rzeczy Pospolitej. Kraków 2007, s. 73.

Zapewne to data według starego stylu; zatem było to 11/23 I 1815. Kolejne daty w tej części artykułu będą podawane w zapisie podwójnym, z uwzględnieniem obu kalendarzy: juliańskiego i gregoriańskiego, $z$ wyjątkiem tych, które dotyczą okresu już porewolucyjnego.

L. S o kół (Ludwik Sztyrmer. Historia życia i twórczości. W: L. Sz ty r m e r, Powieści nieboszczyka Pantofla. Warszawa 1978, s. 570) nazywa ów kodeks „przedziwną rękopiśmienną książeczką”, sugerując incydentalność tego typu tekstu. Warto zwrócić uwagę, że podobny napisał wcześniej S. J a c h o w i c z (Do mojej przyszłej w którejkolwiek świata stronie. W: Wiersze Stanisława Jachowicza poświęcone własnej rodzinie. Bibl. Narodowa, rkps 5778 III, k. 5-6), przeznaczając go dla drugiej swojej żony, Antoniny z Ośniałowskich.

Data urodzenia według inskrypcji nagrobnej z cmentarza na Rossie. 
W przyszłości zostanie ona żoną Narcyza Szulca ${ }^{53}$, inżyniera, rzeczywistego radcy stanu, i matką czworga dzieci: Wacława, Ludwika, Aleksandra i Marii (Dijakiewiczowej ${ }^{54}$ ). Umrze jako wdowa - w Wilnie, $7 / 20$ XII $1904^{55}$. W niewiele lat później Sztyrmerowie doczekali się narodzin syna, nie wymienianego przez żadnego $\mathrm{z}$ biografów, a przecież to właśnie „przy kolebce syna Leonka” powstawać miały Dusza $w$ suchotach i Trupia główka. Leon Marian (Lew; 1842-1852) przyszedł na świat 5/17 I $1842^{56}$, jego ojcem chrzestnym był Romuald Podbereski ${ }^{57}$; dziecko przeżyło 10 lat, zmarło 13/25 I 1852 w Petersburgu ${ }^{58}$. Druga córka Sztyrmerów - Maria Michalina (1847-1852) - zmarła w Petersburgu jako pięciolatka 28 I / 9 II 185259, po dwu tygodniach od zgonu Leona (dzieci zapadły zapewne na jakąś zakaźną chorobę). Informację o kolejnym potomku wnosi inskrypcja nagrobna $z$ cmentarza na Rossie, z której wynika, iż trzecia ich córka, Helena (1848-1920), urodziła się wkrótce po Marii; wyszła za mąż za nie znanego z imienia Godlewskiego, a zmarła 19 VIII 1920 w Wilnie. Najmłodszym z grupy zidentyfikowanych pod względem chronologicznym dzieci Sztyrmerów był - jak się zdaje - Paweł, urodzony we wrześniu 1850; żył tylko 10 miesięcy, zmarł 26 VI / 8 VII 1851, również w Petersbur$\mathrm{gu}^{60}$. Zarówno on, jak i dwoje zmarłych pół roku później rodzeństwa zostali pochowani na Cmentarzu Smoleńskim. Oprócz wymienionych tu pięciorga dzieci mieli jeszcze Sztyrmerowie dwu synów: Konstantego, który został lekarzem, oraz Jana - urzędnika i radcę stanu. Niestety, nie udało się ustalić dat granicznych dotyczących życia tych osób ${ }^{61}$.

Należy też sprostować błąd, który polega na niewłaściwym wskazaniu miejsca zgonu pisarza. Nie był to Landwarów ${ }^{62}$ pod Trokami ani tym bardziej Petersburg $^{63}$. Według aktu zgonu Ludwik Ludwikowicz Sztyrmer zmarł 23 V / 4 VI 1886 w Wilnie ${ }^{64}$. Eleonora Sztyrmerowa przeżyła męża o 5 lat, zmarła w wileńskiej dziel-

Zgodnie z aktem urodzenia Marii Szulc (późniejszej Dijakiewicz) jej ojciec miał na imię Albert i był wówczas (1863 r.) porucznikiem Korpusu Linii Komunikacyjnych. Rodzicami chrzestnymi byli: generał-major Ludwik Sztyrmer i żona podpułkownika, Karolina Szulc. Zob. USC parafii (św. Katarzyny) Petersburg. Nacyjanalny histaryczny archiu Biełarusi w Mińsku, sygn. F.1781, o. 30, d. 285, akt urodzenia $\mathrm{nr} 8 / 1863$.

Maria Ludwika Dijakiewiczowa (8/20 XII 1862 - 1939), zmarła w Ostrowie Wielkopolskim, ale pochowana została na wileńskiej Rossie, w kwaterze rodzinnej. Była w posiadaniu materiałów po dziadku. Mr o ze k (op. cit., s. 9) błędnie podaje jej imię: Aleksandra (myląc z imieniem matki), i upraszcza nazwisko - Djakiewiczowa. USC parafii (św. Jana) Wilno. Lietuvos Valstybės Istorijos Archyvas, sygn. F. 1667, o. 1, d. 31, akt zgonu nr 1246/1904. Data urodzenia obliczona na podstawie dokładnych danych $\mathrm{z}$ aktu zgonu. Zob. List R. Podbereskiego do J. I. Kraszewskiego, z 18 lutego / 2 marca 1842. Petersburg, rkps. Bibl. Jagiellońska, sygn. 6457IV, k. 121c. USC parafii (św. Katarzyny) Petersburg. Nacyjanalny histaryczny archiu Biełarusi w Mińsku, sygn. F.1781, o. 30, d. 283, akt zgonu nr 16/1852.

Jw., akt zgonu nr 32/1852.

Jw., akt zgonu nr 244/1851.

W akcie zgonu Ludwika Sztyrmera wymienia się czworo żyjących dzieci: Konstantego, Jana, Aleksandrę i Helenę.

Zob. Kija s, op. cit., s. 146.

Zob. Chmielowski, op. cit., s. 300.

USC parafii (św. Jana) Wilno, sygn. F. 1667, o. 1, d. 14, akt zgonu nr 221/1886. 
nicy Śnipiszki ${ }^{65} 25$ VII / 6 VIII $1891^{66}$. Oboje spoczywają na wileńskiej Rossie, ich grób jest zachowany do dziś w dobrym stanie ${ }^{67}$.

\author{
Abstract \\ DOROTA SAMBORSKA-KUKUĆ University of Łódź \\ ORCID: 0000-0002-1943-6694 \\ DARIUSZ KUKUĆ
}

\title{
CORRECTIONS AND SUPPLEMENTS TO LUDWIK SZTYRMER'S GENEALOGY AND BIOGRAPHY
}

The article concerns the figure of a writer, an author of unusual prose, referred to as "a Polish Hoffmann." Sztyrmer's life, as it may seem, has been subject of many discussions, and more than that since his writing had also autobiographical valour. The present paper only in a slight degree refers to Sztyrmer Ludwik entry placed in one volume of Polski słownik biograficzny (Polish Biographical Dictionary), and this entry, as defective, became an excuse to start an intensive archive search query.

The paper introduces a set of new pieces of information about Sztyrmer, his family commitments (data on his parents and grandparents, on numerous siblings, both whole and half, i.e. from his mother's first marriage, on his relatives mentioned in his memories). Light is also shed on the issue of Sztyrmer's marriage and his descendants, established names, and real dates of his life.

65

66

67

Miejsce zgonu precyzuje Walicki (op. cit.).

USC parafii (św. Jana) Wilno, sygn. F. 1667, o. 1, d. 15, akt zgonu nr 387/1891.

Obecnie istniejący pomnik wzniosła, jak głosi napis nagrobny, wnuczka, zapewne Maria z Szulców Dijakiewiczowa, która zresztą spoczęła w tej samej kwaterze obok dziadków. Tu także znajdują się mogiły dwóch córek Sztyrmera: Aleksandry Szulc i Heleny Godlewskiej. 